\title{
READY-TO-EAT MEAT AND POULTRY PIES AS A SOURCE OF POTENTIAL PATHOGENS IN ASSUIT CITY
}

LUBNA M. EBRAHEEM and GHADA M. MOHAMED

Animal Health Research Institute, Assiut Regional Laboratory.

\section{ABSTRACT}

Received at: 1/3/2012

Accepted: 9/4/2012
Atotal of 80 samples of pies, 40 each of meat and poultry pies were collected from different restaurants of Assiut city and analyzed bacteriologically (count of aerobic bacteria, coliform, faecal coliform Staph aureus, E.coli and isolation of Staph aureus, Clostridium perfringens, Escherichia coli and Listeria monocytogenes). The mean values of aerobic plate count and Staph. aureus counts were $8 \times 10^{4}$ and $5 \times 10 \mathrm{cfu} / \mathrm{g}$ of examined meat pies while that of poultry pies were $8.3 \times 10^{5}$ and $6 \times 10^{2}$ $\mathrm{cfu} / \mathrm{g}$ respectively. A signifhcant difference in such counts was observed between the two types of pies examined. Regarding the MPN of coliform and faecal coliform, the mean values were $1.1 \mathrm{X} 10$ and $0.5 \mathrm{X} 10$ for meat pies whereas the corresponding values for poultry pies were 0.7 X10 and 0.5 X10 respectively. However, Staph. aureus, Clostridium perfringens, Escherichia coli and Listeria monocytogenes were isolated from $82.5,17.5,7.5$ and $15 \%$ of the examined meat pies while poultry pies contained such organisms in 77.5,12.5,12.5 and $22.5 \%$ of the examined samples. The public health importance of recovered microorganisms as well as some recommended measures for improving the quality of such products were discussed.

Key words: Meat pies, poultry pies, potential pathogens.

\section{فطائر اللحوم والاجاج المعدة للأكل كمصدر محتمل لمسببات الأمراض في مدينة أسيوط}

\section{لبنحى محمد /بر/هيم ، غادة محمد محد}

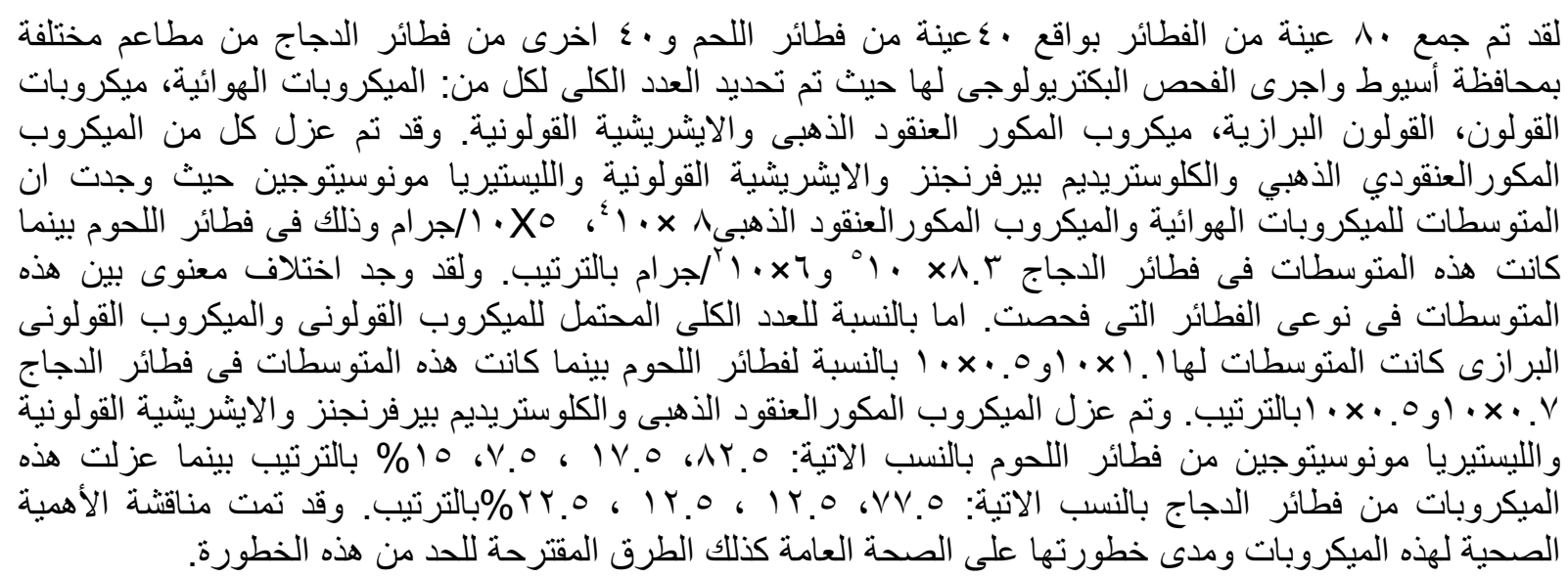




\section{INTRODUCTION}

Ready-to-eat foods could be raw or cooked, hot or chilled and can be consumed without further heat treatment (Tsang, 2002).

Examples of such foods included meat pies and poultry pies. This situation however has resulted in more ready to-eat-foods taken outside home, this food vendor services become on the increase and responsibility for good manufacturing practices of food such as good. The sanitary measures and proper food handling must be improved, because venders can transfer diseases between families through ready-to-eat foods (Musa and Akande, 2002).

Mishandling in food service establishment can contribute significant outbreaks of foodborne disease (Frazier and Westhoff, 2001), also these outbreaks are caused by foods that are contaminated intrinsically (Torok et al., 1997). Because of modern processing methods, handling and distribution, it takes longer for food to reach the table, and it is more likely to be contaminated with microorganisms. (Marriot, 1997).

Staph. aureus, Clost. perfingens and Escherichia coli are bacteria that cause food poisoning. Food infection is the second type of foodborne illness. It is caused by eating food that contain certain types of live bacteria which are present in the food. Once the food is consumed, the bacterial cells themselves continue to grow and illness can result, Listeria is a good example of foodborne infection. Each year, thousands of individuals suffer from the discomfort and pain resulting from foodborne illness. True food poisoning or food intoxication caused by eating food that contains a toxin or poison due to bacterial growth in food (Estes et al., 2003).

It is extremely difficult to eliminate contamination of food completely, but it is easier to control further multiplication of pathogens and stop the forms that produce toxins (Bryan et al., 1991). The bacteria which produced and excreted the toxic waste products into the food may be killed, but the toxin they produced causes the illness or digestive upset to occur (Estes et al., 2003).

Prevention of foodborne infections is based on: pathogen-free food production, hazard control in food processing, surveillance for foodborne illness, and safe food handling by consumers and food-service workers (Doyle, 1993). The practices developed by professionals to ensure the safety of food production and processing are based primarily on knowledge of microbiology (Altekruse et al., 1996).

Since the rules of how to avoid food poisoning are known, the problem in mass catering is enforcement which must include not only proper equipment and installations but also training of personnel (Teuber, 1992).

As there is scarce of information about the bacterial status of pies in Assiut City therefore the aim of this study was focused to assess the bacteriological quality of meat and poultry pies in Assiut governorrate.

\section{MATERIALS and METHODS}

To ascertain the levels and types of bacteria present in meat and poultry pies, 40 samples of each ready-to-eat products were obtained from randomly selected restaurants of Assiut City and examined on the day they were collected for:

1- Total colony count (APC): APHA (1992).

2- Coliform count, Faecal coliform count, E.coli count (MPN/g): AOAC (1990).

3- Staph. aureus count: APHA (1992).

4- Isolation of Staph aureus: Feingold and Martin (1982).

5- Isolation of Listeria monocytogen: Oxoid Manual (1990).

6- Isolation of Clostridium perfringens: Beernes et al. (1980).

7-Isolation of E.coli: AOAC (1990).

All isolates were identified morphologically using staining reaction (APHA, 1992) and motility test (Baron et al., 1994), as well as, biochemically using catalase, coagulase and triple sugar iron (TSI) agar test (Baron et al., 
1994), citrate utilization, indole production, 2001). For further confirmation of methyl red, urease and voges-Proskauer tests L.monocytogenes the isolates were inoculated (Koneman et al., 1992), nitrate reduction test into 10\% aqueous stock solution of Mannitol, (Cowan and Steel, 1974), sugar fermentation L.Rhammose and D.xylose (Collee and reaction (APHA, 1992), Christine-Alkine- Miles, 1989).

Munch- Peterson (CAMP) test (Herrera,

\section{RESUTS}

Table1: Statistical values of aerobic plate count / gram of the examined meat and poultry pies.

\begin{tabular}{lccccccc}
\hline & $\begin{array}{c}\text { No of } \\
\text { exam } \\
\text { samples }\end{array}$ & $\begin{array}{c}\text { No.of } \\
+ \text { ve } \\
\text { samples }\end{array}$ & Minimum & Maximum & Mean & S.E & $\begin{array}{c}\text { P. } \\
\text { value }\end{array}$ \\
\hline $\begin{array}{l}\text { Meat } \\
\text { pies }\end{array}$ & 40 & 40 & $9 \times 10^{3}$ & $2.9 \times 10^{5}$ & $8 \times 104$ & $\pm 1 \times 10^{4}$ \\
\hline $\begin{array}{l}\text { Poultry } \\
\text { pies }\end{array}$ & 40 & 40 & $2.6 \times 10^{4}$ & $6.9 \times 10^{6}$ & $8.3 \times 10^{5}$ & $\pm 4.3 \times 10^{5}$ & $<0.01^{*}$ \\
\hline
\end{tabular}

Table 2: Statistical values of Sstaph aureus count / gram of the examined meat and poultry pies.

\begin{tabular}{|c|c|c|c|c|c|c|c|}
\hline & $\begin{array}{c}\text { No of } \\
\text { exam } \\
\text { samples }\end{array}$ & $\begin{array}{l}\text { No.of }+ \\
\text { ve } \\
\text { samples }\end{array}$ & Minimum & Maximum & Mean & S.E & $\begin{array}{c}\text { P. } \\
\text { value }\end{array}$ \\
\hline $\begin{array}{l}\text { Meat } \\
\text { pies }\end{array}$ & 40 & 31 & $1 \times 10$ & $2 \times 10^{2}$ & $5 \times 10$ & $1.4 \times 10$ & \multirow{2}{*}{$\begin{array}{c}< \\
0.01^{*}\end{array}$} \\
\hline $\begin{array}{l}\text { Poultry } \\
\text { pies }\end{array}$ & 40 & 30 & $4 \times 10$ & $3 \times 10^{3}$ & $6 \times 10^{2}$ & $5 \times 10^{2}$ & \\
\hline
\end{tabular}

Table 3: Statistical values of coliform count (MPN) / gram of the examined meat and poultry pies.

\begin{tabular}{|c|c|c|c|c|c|c|c|}
\hline & $\begin{array}{c}\text { No of } \\
\text { exam } \\
\text { samples }\end{array}$ & $\begin{array}{c}\text { No.of }+ \text { ve } \\
\text { samples }\end{array}$ & Minimum & Maximum & Mean & S.E & $\begin{array}{c}\mathrm{P} . \\
\text { value }\end{array}$ \\
\hline $\begin{array}{l}\text { Meat } \\
\text { pies }\end{array}$ & 40 & 40 & 3.6 & $4.3 \times 10$ & $1.1 \times 10$ & $\pm 0.1 \times 10$ & \multirow{2}{*}{ N.S } \\
\hline $\begin{array}{l}\text { Poultry } \\
\text { pies }\end{array}$ & 40 & 38 & 3.6 & 23 & $0.7 \times 10$ & $\pm 0.1 \times 10$ & \\
\hline
\end{tabular}


Table 4: Statistical values of faecal coliform count (MPN)/gram of the examined meat and poultry pies.

\begin{tabular}{|c|c|c|c|c|c|c|c|}
\hline & $\begin{array}{c}\text { No of } \\
\text { exam } \\
\text { samples }\end{array}$ & $\begin{array}{c}\text { No.of+ ve } \\
\text { samples }\end{array}$ & Minimum & Maximum & Mean & S.E & $\begin{array}{c}P . \\
\text { value }\end{array}$ \\
\hline $\begin{array}{l}\text { Meat } \\
\text { pies }\end{array}$ & 40 & 36 & 3.6 & $1.1 \times 10$ & $0.5 \times 10$ & $\pm 0.04 \times 10$ & \multirow{2}{*}{ N.S } \\
\hline $\begin{array}{l}\text { Poultry } \\
\text { pies }\end{array}$ & 40 & 35 & 3.6 & $1.5 \times 10$ & $0.5 \times 10$ & $\pm 0.08 \times 10$ & \\
\hline
\end{tabular}

N.S: non significant

* : Significant

Table 5: Frequency distribution of meat and poultry pies based on their E.coli count $(n=40$ of each).

\begin{tabular}{ccccc}
\hline \multirow{2}{*}{ Interval } & \multicolumn{3}{c}{ Meat pies } & \multicolumn{2}{c}{ Poultry pies } \\
\cline { 2 - 5 } & No. & $\%$ & No. & $\%$ \\
\hline$<3$ & 38 & 95 & 37 & 92.5 \\
\hline $3-<6$ & 1 & 2.5 & 3 & 7.5 \\
\hline $6-<9$ & 1 & 2.5 & - & - \\
\hline
\end{tabular}

Table 6: Incidence of the isolated organisms from the examined meat and poultry pies.

\begin{tabular}{lcccccc}
\hline \multirow{2}{*}{ Organisms } & \multicolumn{3}{c}{ Meat pies } & \multicolumn{3}{c}{ Poultry pies } \\
\cline { 2 - 7 } & $\begin{array}{c}\text { No. of } \\
\text { exam. } \\
\text { samples }\end{array}$ & $\begin{array}{c}\text { No. of } \\
+\mathrm{ve} \\
\text { samples }\end{array}$ & $\%$ & $\begin{array}{c}\text { No. of } \\
\text { exam. } \\
\text { samples }\end{array}$ & $\begin{array}{c}\text { No. of } \\
+ \text { ve } \\
\text { samples }\end{array}$ & $\%$ \\
\hline Staph aureus & 40 & 33 & 82.5 & 40 & 31 & 77.5 \\
\hline C.perfrengenes & 40 & 7 & 17.5 & 40 & 5 & 12.5 \\
\hline E.coli & 40 & 3 & 7.5 & 40 & 5 & 12.5 \\
\hline L.monocytogenes & 40 & 6 & 15 & 40 & 9 & 22.5 \\
\hline
\end{tabular}




\section{DISCUSSION}

Regulatory agencies and industrial quality assurance regularly examine foods or ingredients for microorganisms or their metabolic productsthat may indicate: (1) The possible presence of a pathogen or harmful toxins, (2) The possibility that faulty practices occurred during production, processing, storage and distribution, and for (3) The suitability of a food or ingredient for a desired purpose (NAS, 1985).

The standard plate count is one of the most common tests applied to indicate the microbiological quality of food. High count may indicate the product may have been prepared unhygienically or stored inappropriately (ICMSF, 2001).

The results recorded in Table 1 reveal that all the examined samples $(100 \%)$ contained arobic bacteria in numbers varied from $9 \mathrm{x}$ $10^{3}$ to $2.9 \times 10^{5}$ with a mean value of $8 \pm 1 \mathrm{x}$ $10^{4} \mathrm{CFU} / \mathrm{g}$, in meat pies while in poultry pies the numbers varied from $2.6 \times 10^{4}$ to $6.9 \times$ $10^{6}$ with a mean value of $8.3 \pm 4.3 \times 10^{5}$ $\mathrm{CFU} / \mathrm{g}$. There was a comparable difference $(\mathrm{P}<0.01)$ between the mean total microbial counts between meat pies and poultry pies.

The high microbial counts may be due to meat offers a rich nutrient media for microbial growth (Phillips, 2003). Also this is an indication of recontamination in food handling hygiene techniques starting from the processing of the raw material to the finished product (Ikeme, 1990; Ojeibun, 1994). Higher counts of aerobic bacteria in meat pies were also enumerated by Alexander and Tittiger (1971), and a lower figure $3 \times 10^{3}-5 \times 10^{3} \mathrm{CFU} / \mathrm{g}$ was reported by Yah clarence et al. (2009).

Table 2 showed the statistical values of Staph aureus (CUF/g) of the examined meat and poultry pies, the count ranged between $1 \mathrm{x}$ $10^{1}$ and $2 \times 10^{2}$ with a mean value of $5 \pm 1.4 \times$ $10^{1} \mathrm{CFU} / \mathrm{g}$ meat pies and ranged between 4 $\times 10^{1}$ and $3 \times 10^{3}$ with a mean value of $6 \pm 5$ $\mathrm{x} 10^{2} \mathrm{CFU} / \mathrm{g}$ in poultry pie, that a significance difference was apparent between them $(\mathrm{P}<0.01)$. Higher counts of Staph aureus in meat pies were recorded by El-
Gohary (1994) and Yah Clarence et al. (2009).

The significance difference $(\mathrm{P}<0.01)$ which showed in both of total microbial counts and Staph aureus counts between meat pies and poultry pies could be attributed to the ingredients used and the processing difference.

Results of coliform count (MPN/g) indicated in Table 3 verify that the minimum value of coliform in meat pies was 3.6, the maximum value was $4.3 \times 10^{1}$ and the mean value was $1.1 \times 10^{1} \pm 0.1 \times 10^{1}$, while in poultry pies the minimum, maximum and mean values were $3.6,23$ and $0.7 \times 10^{1} \pm 0.1 \times 10^{1}$, respectively.

According to the data summarized in Table 4 , the faecal coliform count (MPN/g) varied from 3.6 to $1.1 \times 10^{1}$ with a mean value of $0.5 \times 10^{1} \pm 0.04 \times 10^{1}$ in meat pies and this count varied from 3.6 to $1.5 \times 10^{1}$ with a mean value of $0.5 \times 10^{1} \pm 0.08 \times 10^{1}$ in poultry pies.

Regarding meat pies, two samples had E.coli where the MPN for each lied between $3-<6$ and $6-<9 / \mathrm{g}$ whereas poultry pies revealed the presence of E.coli in 3 samples only where the MPN lied between $3-<6 / g$ as recorded in Table 5.

There was no significant difference between meat pies and poultry pies in coliform and faecal coliform counts as recorded in Tables 3 and 4.

Results given in Table 6 revealed that $82.5 \%$ and $775 \%$ of Staph aureus were isolated from meat and poultry pies respectively, this percent was higher than that obtained by Alexander and Tittiger (1971) (22.7\%) in meat pies. Staphylococcus is a true food intoxication organism. It produces a heat stable toxin when allowed to grow for several hours in foods such as chicken pies. This bacterial growth may not cause any off color, odor, or textural or flavor changes, but the toxin will be secreted into the food. This organism grows best at body temperature $\left(36.6{ }^{\circ} \mathrm{C}\right)$, but it can grow over the much wider range of $10{ }^{\circ} \mathrm{C}$ to $46.1^{\circ} \mathrm{c}$. the best prevention of staph food poisoning is to 
properly store food and reduce the temperature below 40 degree $\mathrm{F}$ within four hours after preparation of serving. In order for Staph to grow and produce toxin, it must have sufficient time, approximately two to four hours. Therefore, it is important to cool or heat foods through the danger zone of $4.4^{\circ} \mathrm{C}$ to $60^{\circ} \mathrm{C}$ as rapidly as possible.

C.perfringens was found in 7 samples of meat pies $(17.5 \%)$ and in 5 samples of poultry pies (12.5\%) (Table 6). Alexander and Tittiger (1971) reported that clostridia were found in low numbers in some samples of meat pies.

C.perfriongens can grow over a wide range of temperature, but grows very slowly at low temperatures, these bacterial spores will germinate and grow best at temperatures between $37.7 \circ \mathrm{C}$ and $47.2{ }^{\circ} \mathrm{C}$.

Many foods such as meat and poultry may carry the organism, but the mere presence of C.perfringens in food is not enough to cause illness. Millions of growing cells are needed. The prevention of growth of this organism is best accomplished by following the standard food service practices of rapidly chilling prepared foods in shallow containers and keeping cold food cold and hot food hot, also reduce the level of contamination by keeping all work areas clean and sanitary (Estes et al., 2003).

Results given in Table 6 revealed that $7.5 \%$ of E-coli were isolated from 3 out of 40 samples of meat pies and $12.5 \%$ were isolated from 5 out of 40 sampels of poultry pies. Alexander and Tittiger (1971) reported that the incidence of samples (Meat pies) containing coliform was high $(81.6 \%)$, while Yah Clarene et al. (2009) cited the count of E.coli in meat pies as $2 \times 10^{3} \mathrm{CFU} / \mathrm{g}$.

According to Edema et al. (2001), Okonko et al. $(2008 \mathrm{a}, \mathrm{b})$ the presence of E.coli in food is an indication of faecal contamination of the water sources that were utilized in the processing of these food products. Also Edema et al. (2005) reported that biological contaminants of bacterial origin present as major cause of foodborne disease given rise to acute to chronic illnesses such as E.coli gastroenteritis, brucellosis and campylobacteriosis.

Listeria monocytogenes was detected in our study in $15 \%$ of meat pies and in $22.5 \%$ of poultry pies (Table 6).

This organism is a food infection bacteria gaining in public awareness as a safety problem in food products. The general growth conditions required are oxygen, temperatures ranging from $2.7 \mathrm{C}^{\circ}$ to $40 \mathrm{C}^{\circ}$ and a $\mathrm{pH}$ range of 5.6 to 9.8 , since Listeria can grow at refrigerated temperatures. The organism is generally destroyed by heat treatment, $76.6{ }^{\circ} \mathrm{C}$ for 15 seconds. Proper personal hygiene, good sanitation, proper cooking and preventing cross contamination of raw and cooked food are the best control measures known to date (Estes et al., 2003).

Thus to safeguard against the risks of detected microorganisms, there is need to educate and advocate for good manufacturing practices among food processors and food vendors.

Betty and Richard 1994, said that food poisoning / illnesses are entirely preventable by practicing good sanitation and food handling techniques.

In conclusion, a mong the requirement of any food to be of good sanitary quality, it must be free from hazardous microorganisms, or these present should be at a safe level. Therefore, standards for composition and bacterial content are now adopted by nearly all countries. so that public may be assured of a safe healthful product.

The information given by the achieved results proved that most of the examined meat and poultry pies contained valiable numbers and types of microorganisms which may be responsible for inferior quality of the product and increase the risk of public health. Therefore, food safety standards should be applied and Hazard Analysis Critical Point (HACCP) should be applied throughout processing and distribution of the product. 


\section{REFERENCES}

Alexander, D.C. and Tittiger, F. (1971): Bacteriological studies on meat pies and frozen prepared dinners. Can. J. Comp. Med. Vo. 35: 5-11.

Altekruse, S.F; street, D.A; Fein, S.B and Levy, A.S. (1996): Consumer knowledge of foodborn microbial hazards and handling practices. J. Food Prot. 59, 3: 2287-294.

AOAC "Association of Official Analytical Chemists" (1990): Official Methods of Analysis of the Association of Officical Analytical Chemists. $15^{\text {th }}$ Ed. Inc. USA. AOAC.

APHA "American Public Health Association": (1992): Compendium of Methods for the Microbiological Examination of Foods $3^{\text {rd }}$ Ed. Washington, D.C. USA. APHA.

Baron, Ellen, J. O.; Perteson, L. R.; Finegold and Sydney, M. (1994): Bailey and Scott's Diagnostic Microbiology. $9^{\text {th }}$ Ed Shanahan J.F. (edit). Mosby year Book, Inc.

Beernes, H.; Romond, C.; Lepage, C. and Crquelion, J. (1980): A direct method for the enumeration of Clostridium perfringens in foods and faeces. World Congress foodborne infections. Berlin (West).

Betty, C.H. and Richard, J.B. (1994): Bacterial causes of food poisoning in food poisoning and hygiene, $8^{\text {th }} \mathrm{Ed}$. Edward Annod. Publishing Limited London PP. 250-257.

Bryan,F.L.; Fukunaga, I.; Tsutsumi, S.; Niyashiro, L.; Kagawa, D.; Sakai, B.; Mastuura, H. and Ormarura, M. (1991): Hazard analysis of Japanese mixed lunches (bento). J. Environ. Health 54: 29-32.

Collee, J.G. and Miles, R.S. (1989): Tests for identification of bacteria Mackie and McCartney Practical Medical Microbiology, J.G. Collee, J.P. Duguid, A.G. Fraser and B.P. Marmion (eds.) Vol. 11, 13 Ed, Churchill living stone Edinburgh, London, PP: 141-159.

Cowan, S.T. and Steel, K.J. (1974): Manual for Identification of Medical Bacteria, $2^{\text {nd }}$
Ed. Campridge, Campridge Unif. Press.

Doyle, M.P. (1993): Reducing foodborne disease-hat are the priorities? Nutr. Rev., 51: 345-34.

Edema, M.O.; Omemau, A.M. and fapetu (2001): Microbiology and physicochemical analysis of different sources of drinking water in Abeokuta Nigeria. Nig. J. Microbiol. 15 (1): 57-61.

Edema, M.O.; Atayese, A.O. and Idowu, A.O. (2005): Microbiological quality of microwave processed foods. In: the Book of Abstract of the $29^{\text {th }}$ Annual conference and general meeting on microbes as agents of sustainable development. Organized by Nigerian Society for Microbiology (NSM), UNAAB, Abeokuta from 6-10 ${ }^{\text {th }}$ Nov. P. 17.

ElGohany, A.H. (1994): Susage and minced meat as a source of food poisoning microorganisms to man. Assiut. Vet. Med. J. 30: 146-215.

Estes, R.; George, S.; William, H. and Typor, P.T. (2003): Preventing food poisoning and food infection the University of Georgia, College of Agricultural and Environmental Sciences cooperative extension service.

Feingold, S.M. and Martin, W.J. (1982): Bailey and Scott Diagnostic. Microbiology. $6^{\text {th }}$ Ed. C.V. Mosby. Co. St. Louis, Toronto, London.

Frazier, W.C. and Westhoff, D.C. (2001): Food Microbiology, Tata McGrow Hill.

ICMSF (2001): "International Commission on Microbiological Specifications" for Foods. Guidelines for the microbiological examination of ready-to-eat food. December: 18-23.

Herrera, A.G. (2001): Listeria monocytogenes. In food Microbilogy Protocols. Spencer, J.F.T. and Ragout de Spencer (edit). Humana Press Inc. Totowa, New Jersy.

Ikeme, A.L. (1990): Fermental sausage-dry and semidry. Meat Science and Technology $1^{\text {st }}$ Ed. The African fep Publisher Llimited Nigeria P. 210.

Koneman, E.W.; Schrechenberger, P.C.; Allen, S.D.; Winn, W.C. and Janda, W.M. (1992): Color Altas and Textbook of Diagnostic Microbiology, $4^{\text {th }}$ Ed. 
Winters, R. (edit). J. B. Lippincott company, Philadelphia.

Marriott, N.G. (1997): Essentials of food sanitation. Chapman and Hall, 115 Fifth Avenue, New York, NY 10003.

Musa, O.L. and Akande, T.M. (2002): Effect of health education intervention or food safety practice among food vendors in llorin. Sahel Med. J. 5: 120-124.

NAS"National Academy of Science"(1985): An Evaluation of the Role of Microbiological Criteria for Foods and Food Ingredients. National Academy Press. Washington, D.C.

Ojeibun, F.I. (1994): Isolation of Staphylococcus aureus and other bacteria from some ready to eat foods sold in Benin City. B. Sc. Hon Thesis University of Benin, Benin City P. 100.

Okonko, I.O.; Adejoye, O.D.; Ogunnusi, T.A.; Fajobi, E.A. and Shittu, O.B. (2008 a): Microbiological and physicochemical analysis of different water samples used for domestic purposes in Abeokuta and Ojota, Lagos State, Nigeria, Afr. J. Biotechnol. 7 (3): 617-621.

Okonko, J.O.; Ogunjobi, A.A.; Adejoye, O.D.; Ogunnusi, T.A. and Olasogba, M.C. (2008b): Comparative studies and microbial risk assessment of different water samples used for processing frozen sea-foods in Ijoraolopa, Lagos State, Migeria. Afr. J. Biotechnol. 7 (16): 29022907.
Oxoid Manual (1990): Listeria species and listeriosis $6^{\text {th }}$ Ed. Unipath Limited, Waderoad, Basingstoke, Hampshire, England.

Phillips, M. (2003): Analysis of Microbial Hazards related to time/ temperature control of foods for safety comprehensive review in Food Science and Food Safety 2: 33-35.

Teuber, M. (1992): Special problems of mass catering 3rd World Congress Foodborne Infection and Intoxication, Vol.II, 16-19 June, Berlin.

Torok, T.J.; Tauze, R.V.; Wise, R.P.; Livengood, J.R.; Sokolow, R. and Manvans, S. (1997): A large community outbreak of salmonellosis caused by international contamination of a restaurant salads/ bars. J. Am. Med. Assoc. 278 (8): 389-395.

Tsang, D. (2002): Microbiological guidelines for ready to eat food. Road and Environmental Hygiene Department Hong. Kong PP. 115-116.

Yah Clarence, S.; Nwinyi Obinna, C. and Chinedu shalom, N. (2009): Assessment of bacteriological quality of ready to eat food (Meat pie) in Benin City metropolis, Nigeria, African Jounral of Microbiology Research. 3 (6): 390-395. 